\title{
Water Absorption and the Genetic Relationship of Four Different Types of Acha (Digitaria exilis) Grains Using PCR
}

\author{
M. F. Istifanus ${ }^{1 *}$, E. B. Agbo ${ }^{2}$ and A. F. Umar ${ }^{2}$ \\ ${ }^{1}$ Department of Microbiology, Plateau State University, Bokkos, Plateau State Nigeria \\ ${ }^{2}$ Department of Biological sciences, Abubakar Tafawa-Balewa University Bauchi, \\ Bauchi State, Nigeria \\ *Corresponding author
}

\section{A B S T R A C T}

\section{Keywords \\ Extraction, water absorption steeping \\ Article Info \\ Accepted: \\ 26 May 2018 \\ Available Online: \\ 10 June 2018}

The genomic DNA extraction of four different Acha types based on colour (yellow, brown, cream and white) was carried out using five (5) set of microsatellite primers. The PCR result revealed the genetic relationship and difference between the Acha types, where two of the primers did not amplify the grain, whereas three did. The water absorption behaviors of the grains were also determined using two water temperatures $35^{\circ} \mathrm{c}$ and $50^{\circ} \mathrm{c}$. There was an initial rapid rate of water absorption within the first hour which later reduces and become steady from 6 hours up to the $24^{\text {th }}$ hours of steeping. The summary of the analysis reveals that yellow, brown and white colour types are not significantly different at $\mathrm{p}$-value confidence level.

\section{Introduction}

Cereal grain which could be used to produce variety of dishes requires preliminary preparation, such as soaking and washing in water, fermentation and milling to produce fine flour and grits. The treatment used depends on the product to be produced, (Addo et al., 2006). During the soaking of food materials water is progressively being absorbed the extent of absorption depends primarily on the soaking water temperature, time and physio chemical properties of the food material. Soaking is the most common preliminary process applied to Acha grain during the production of various Acha based food product like masa, kunun-zaki, pap etc.
(Shittu et al., 2004). Acha is of different varieties, the report of CIRAD, (2004) says there are over 300 digitaria species which are sometimes grown as fodder, only three or four are sometimes grown as cereals.

In a similar study carried out by (Istifanus and Agbo, 2016), fourteen (14) different varieties of Acha grain were identified from four selected local Governments of Bauchi and Plateau states. Due to the variations that exist in Acha grain, the need for genetic characterization is very important which will reveal a lot of information on the taxonomy, cytogenetic and compatibility of the grain. It will also help in improving the agronomic and quality characteristic of the grain through 
higher yielding accession. (Kwon-Ndung and Dachi, 2007).

This work is therefore, aimed at studying the genetic relationship of four different types of Acha grain using PCR, and to also optimized the water absorption behaviour of the grains.

\section{Materials and Method}

\section{Optimisation of Maximum Moisture Uptake}

About $10 \mathrm{~g}$ of each of the grains was soaked in $50 \mathrm{ml}$ of distilled water in a $100 \mathrm{ml}$ beaker. Weight gain during soaking at $35^{\circ} \mathrm{C}$ and $50^{\circ} \mathrm{C}$ was determined. The grains were kept, at room temperature $\left(35^{\circ} \mathrm{C}\right)$ and in a water bath (sodeteg, TE7, France and Labovolt 81015) at $50^{\circ} \mathrm{C}$. Weight of soaked grains were taken at an interval of 1 to 6-hour period and at $24 \mathrm{~h}$ periods. The soak water was drained off the grains by the use of a sieve; the free water was allowed to drain from the grain. Water absorbed by the grains with respect to soaking time was determined by subtracting the original weight of grains from the weight of the water - absorbed grains (Seyhan-Gurtaset al., 2001). Soaking of grains in water continued until they stopped absorbing water (i.e the moisture absorption capacity was reached). Total solid of the soaking water for each beaker containing the $10 \mathrm{~g}$ for each Acha grain was determined at each interval of time, by evaporating off the water with a laboratory oven (prolabo, 53921) at $110^{\circ} \mathrm{C}$ until dryness. Total solids of the soak water were determined and added to the weights gained during soaking to obtained correct weight without solid loss. (Tagawa et al., 2003).

After which the analysis of variance was carried out using the repeated measure longitudinal analysis method, it is being used when analysing two variables with time. It was used to determine the difference in water absorption rate of the four (4) types of Acha grain used.

\section{DNA Extraction}

The DNA extraction of the four types of Acha samples was done using the simple sequence repeat or microsatellites marker techniques (SSRs) by the protocol described by Yin et al., 2011, but were scaled down so that extraction was done in a $1.5 \mathrm{ml}$ tube. The samples identify are 1.CM, 2. YL, 3.WE and 4.BNthe protocols were as follows: -

Acha grains were grind into power and transferred immediately into a $1.5 \mathrm{ml}$ centrifuge tubes

To each $10 \mathrm{mg}$ sample, 500ul of extraction buffer, was added, the contents were mixed very well and were incubated at $65^{\circ} \mathrm{C}$ for 20minutes with occasional swirling.

After which samples were allowed to cool at room temperature, thereafter, $300 \mathrm{ul}$ volume of chloroform was added, which were incubated on ice for 5 munites.

Next they were centrifuged at $8,000 \mathrm{rmp}$ for 20 munites at $4{ }^{\mathrm{O}} \mathrm{C}$; the supernatants were carefully pipette off to a new free tube.

Steps 3 and 4 were repeated.

$150 \mathrm{ul}$ volume of $8 \mathrm{~m} \mathrm{LiCl}$ was added to each of the tubes mixed gently and was incubated at $80^{\circ} \mathrm{C}$ for $2 \mathrm{hrs}$ or overnight as desired.

After the $2 \mathrm{hrs}$ or overnight, the tubes were centrifuged at $8,000 \mathrm{rmp}$ for 20 munites at $4^{\circ} \mathrm{C}$.

The solutions were then transferred to DNasefree tubes, and then $1 \mathrm{ml}$ volume of ethanol was added and incubated on ice for 30munites. They were centrifuged again, but this time at 10,000rmp for 10minutes. The pellet was 
washed with $75 \%$ ethanol one to two times; air dried the pellet for 10minutes and then dissolved the pellet in 100ul DNase - free water. Now we have our extracted DNA.

\section{DNA Amplification Process}

The genomic DNA extracted from four different types of Acha grains (CM, YL, WE and $\mathrm{BN}$ ) was amplified using five sets of microsatellite primers developed by (Barnaud et al., 2016) as previously described (Table 1). In this process a very small amount of each of the samples of extracted DNA were added to a PCR cocktail for amplification in a thermo cycler.

Table.1 Microsatellite Primers Used and their Reaction Mix Per Sample

\begin{tabular}{|c|c|}
\hline PRIMER SEQUENCE & BASE PAIR \\
\hline De-03F; TTAAGACCATTTGGATTAGAGAA & 111 \\
\hline \multicolumn{2}{|l|}{ De-03R; CTTAAACGCCCAATCTTTAG } \\
\hline De-05F; AAGCCTTGCGTTCTATCTTA & 219 \\
\hline \multicolumn{2}{|l|}{ De-05R; TTAATATGATGCTACCCCTCA } \\
\hline De-23F; CGTGGACTAACGTATCAAGAA & 168 \\
\hline \multicolumn{2}{|l|}{ De-23R; АСТСССТСТССССААТСT } \\
\hline De-30F; GTGCTAGGTGGAGCGAGA & 131 \\
\hline \multicolumn{2}{|l|}{ De-30R; CGTGAGCAGGTTCTCCAG } \\
\hline De-37F; TGAACAAATTCCTCTTGCTC & 198 \\
\hline \multicolumn{2}{|l|}{ De-37R; TGGCAATGTTCCATAAAGA } \\
\hline \multicolumn{2}{|c|}{ The reaction mix per sample is presented below: } \\
\hline REAGENT & $1 X(u l)$ \\
\hline Nuclease free water & 12.0 \\
\hline 10 XPCR buffer & 2.0 \\
\hline Dntp MIX (10Mm) & 0.2 \\
\hline Magnesium Chloride (25mM) & 0.8 \\
\hline Forward primer (4uM) & 1.0 \\
\hline Reverse primer (4uM) & 1.0 \\
\hline \multirow[t]{2}{*}{ GoTaq Polymerase () } & 0.5 \\
\hline & 18.0 \\
\hline DNA template & 2.0 \\
\hline Total reaction Volume & 20.0 \\
\hline
\end{tabular}

Source: Barnaud et al., 2016. 
This is a "magic" step that has revolutionized molecular biology. We started with almost no DNA and wind up with enough that we can see it on a gel. Various "cocktail" recipes existed, they contain the thermophilic bacterial enzyme Taq Polymerase (essential), the dNTP mix (nucleotides that will allow massive replication of the targeted DNA), magnesium chloride, and the fluorescently labelleddNTPs (these will bind to the specially added M13 or T3 tail and light up under the laser and make bands of DNA alleles show up on the gel)

The cycling program for the amplification which was performed on a 9600PCR system (Applied Biosystems) is given below: -

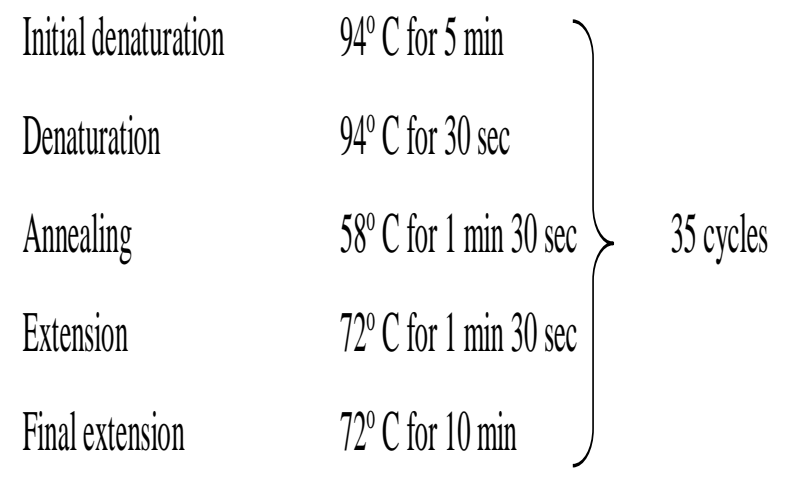

The PCR products were then cooled at +4 o C until used for electrophoresis.

\section{Agarose Gel Preparation}

$1.5 \mathrm{~g}$ of agarose powder was dissolved in $100 \mathrm{ml}$ of TBE buffer $(0.5 \mathrm{X})$ and melted in a microwave for 3 munites to give a $1.5 \%$ agarose gel. 5ul of ethidium bromide was added to the cooking gel before pouring into the gel casting tray. The tray was already fitted with a comb. Once the gel is set, it was transferred into an electro phoretic tank containing 0.5XTBE buffer. 10ul of the amplified product was mixed with $2 \mathrm{ul}$ of loading dye and was loaded into the wells. A $50 \mathrm{bp}$ molecular weight marker was also added. Each set of the reactions had a nontemplate control (negative control).

\section{Sequencing}

The amplified products (gel) were run through the sequencer at 150 volts for 40 minutes until all the alleles have had times to run by the laser, to separate the products.

The process which illuminates the fluorescent nucleotides and makes bands light up on the gel. The sequencer generates an analogue image which was viewed on an ultraviolet transilluminator and captured using a camera.

The major variables in optimization include: temperature (the primer sequence will have a predicted melting temperature but what actually works may be higher or lower), the PCR-programmed times for denaturing, annealing and extending steps Magnesium chloride concentrations.

\section{Results and Discussion \\ Maximum moisture optimization}

The result in Table 2 shows variation in the water absorption characteristics of the four Acha types. This was due to their difference, because water absorption behavior of each food material is unique due to their physiochemical properties (Shittu et al., 2004).

The water absorption at $50^{\circ} \mathrm{c}$ was more rapid than at $35^{\circ} \mathrm{c}$, figure 1 . Generally, more water was absorbed at $50^{\circ} \mathrm{c}$ for all Achatypes; this was as a result of the increase in temperature, because temperature appears to accelerate the rate of water absorption of food materials. This is in agreement with previous works that says an increase in temperature of the soaking medium increases water uptake by various seed which subsequently results in a reduction of the soaking time (Sopade and Obekpa, 1990; Shittu et al., 2004; Addo et al., 2006). 
Table.2 Moisture uptake of Four Different Types of Acha Based on Time Temperature

\begin{tabular}{|c|c|c|c|c|}
\hline \multicolumn{5}{|c|}{ Optimization of Moisture Uptake condition } \\
\hline \multicolumn{3}{|c|}{ Water absorption at 0 time } & \multicolumn{2}{|c|}{ Water absorption after 1 hou } \\
\hline & $35^{\circ} \mathrm{C}$ & $50^{\circ} \mathrm{C}$ & $35^{\circ} \mathrm{C}$ & $50^{\circ} \mathrm{C}$ \\
\hline $\mathrm{YL}$ & $49.20 \mathrm{~g}$ & $50.05 \mathrm{~g}$ & $52.39 \mathrm{~g}$ & $53.29 \mathrm{~g}$ \\
\hline $\mathrm{BN}$ & $47.45 \mathrm{~g}$ & $49.10 \mathrm{~g}$ & $51.02 \mathrm{~g}$ & $52.15 \mathrm{~g}$ \\
\hline $\mathrm{CM}$ & $46.05 \mathrm{~g}$ & $49.02 \mathrm{~g}$ & $50.12 \mathrm{~g}$ & $51.20 \mathrm{~g}$ \\
\hline WE & $48.15 \mathrm{~g}$ & $48.53 \mathrm{~g}$ & $51.69 \mathrm{~g}$ & $52.50 \mathrm{~g}$ \\
\hline \multicolumn{3}{|c|}{ After 2 hours of steeping } & \multicolumn{2}{|c|}{ After 4 hours of steeping } \\
\hline $\mathrm{YL}$ & $53.10 \mathrm{~g}$ & $53.91 \mathrm{~g}$ & $54.05 \mathrm{~g}$ & $54.75 \mathrm{~g}$ \\
\hline BN & $52.35 \mathrm{~g}$ & $53.76 \mathrm{~g}$ & $53.85 \mathrm{~g}$ & $54.60 \mathrm{~g}$ \\
\hline $\mathrm{CM}$ & $51.09 \mathrm{~g}$ & $52.25 \mathrm{~g}$ & $52.56 \mathrm{~g}$ & $53.45 \mathrm{~g}$ \\
\hline WE & $52.22 \mathrm{~g}$ & $53.45 \mathrm{~g}$ & $53.22 \mathrm{~g}$ & $54.05 \mathrm{~g}$ \\
\hline \multicolumn{3}{|c|}{ After 6 hours of steeping } & \multicolumn{2}{|c|}{ After 24 hours of steeping } \\
\hline $\mathrm{YL}$ & $55.56 \mathrm{~g}$ & $55.57 \mathrm{~g}$ & $55.59 \mathrm{~g}$ & $55.59 \mathrm{~g}$ \\
\hline $\mathrm{BN}$ & $55.80 \mathrm{~g}$ & $55.81 \mathrm{~g}$ & $55.83 \mathrm{~g}$ & $55.83 \mathrm{~g}$ \\
\hline $\mathrm{CM}$ & $54.44 \mathrm{~g}$ & $54.46 \mathrm{~g}$ & $54.48 \mathrm{~g}$ & $54.48 \mathrm{~g}$ \\
\hline WE & $54.69 \mathrm{~g}$ & $54.70 \mathrm{~g}$ & $54.71 \mathrm{~g}$ & $54.71 \mathrm{~g}$ \\
\hline
\end{tabular}

Key:

$\mathrm{YL}=\overline{\text { Yellow }} \quad \mathrm{BN}=$ Brown

$\mathrm{CM}=$ Cream

WE = White

Table.3 The Summary of the Moisture Uptake of the Four Colour Types of Acha Grain

\begin{tabular}{|c|c|c|c|c|}
\hline Parameters & $\mathrm{YL}$ & BN & CM & WE \\
\hline $\begin{array}{l}\text { Water Absorption } \\
\mathrm{ml} / \mathrm{g}\end{array}$ & $54.3 \pm 0.28^{a}$ & $54.1+0.135^{a}$ & $52.9 \pm 0.18^{b}$ & $53.6+0.134^{a}$ \\
\hline
\end{tabular}

Values are means of triplicate determination + Standard Deviation

Means with same superscript in each row are not significantly different from each another (LSD, p<0.05).

Key: $\quad$ YL $=$ Yellow $\quad \mathrm{BN}=$ Brown $\quad \mathrm{CM}=$ Cream $\quad \mathrm{WE}=$ White 
Fig.1 The mean and standard deviation of the soaked grain based on time and temperature

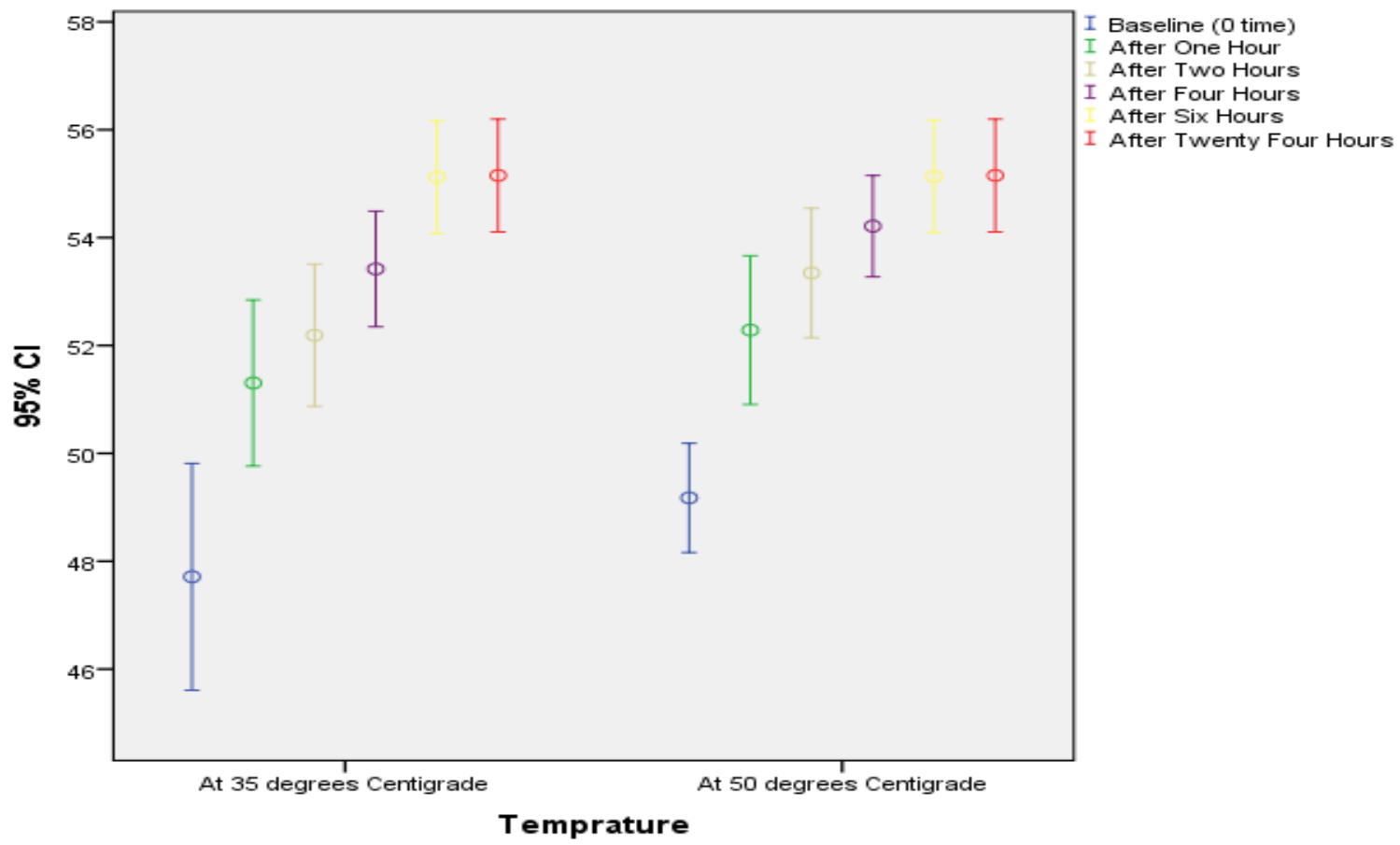

Fig. 2 Comparing the water absorption of the four colour types of Acha based on time and temperature

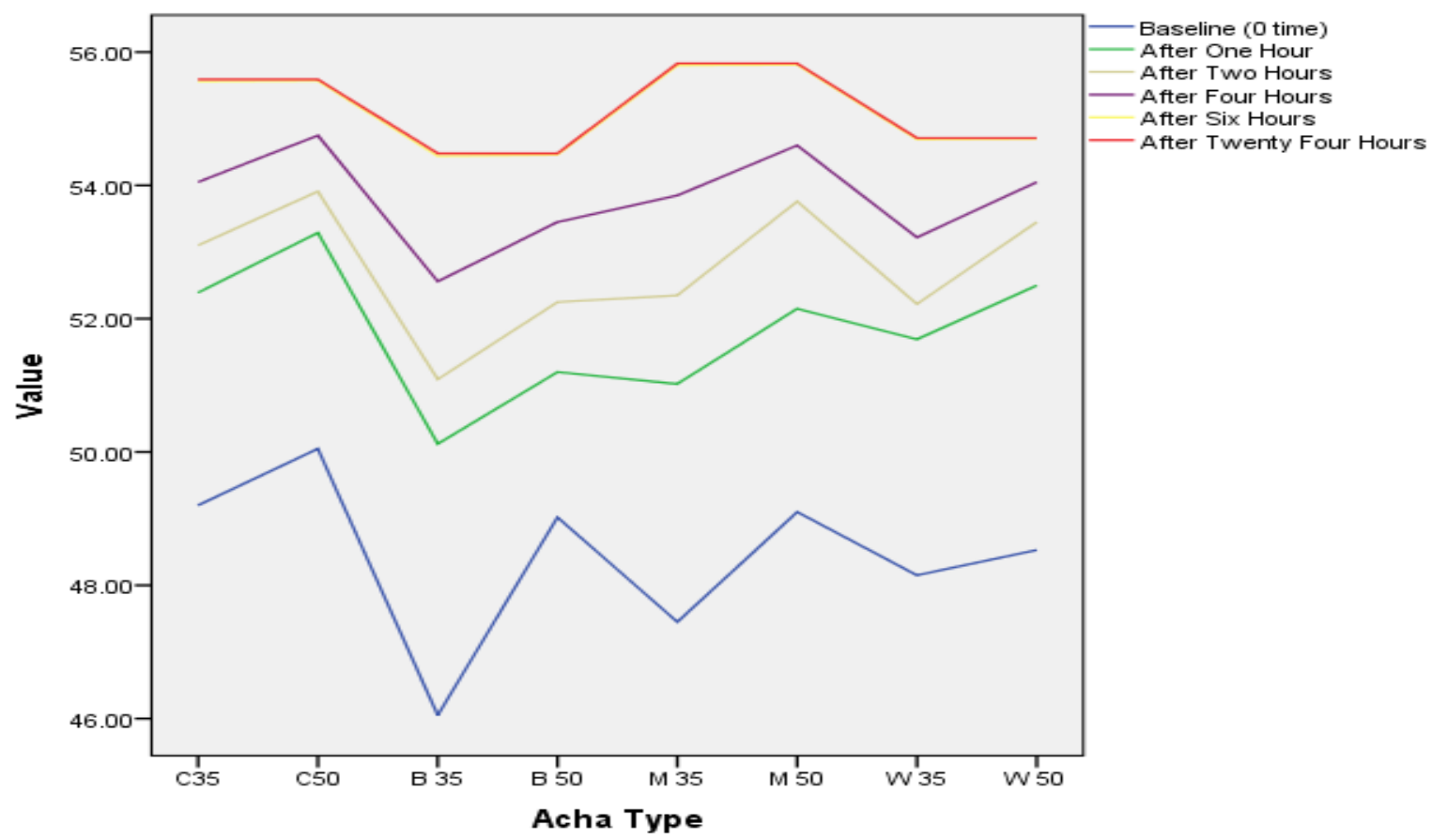

Key: C - creamAcha

B - brown Acha W- white Acha

M - milk Acha 
Fig.3 Gel picture showing the amplification of four Acha types using primers De03 and De05

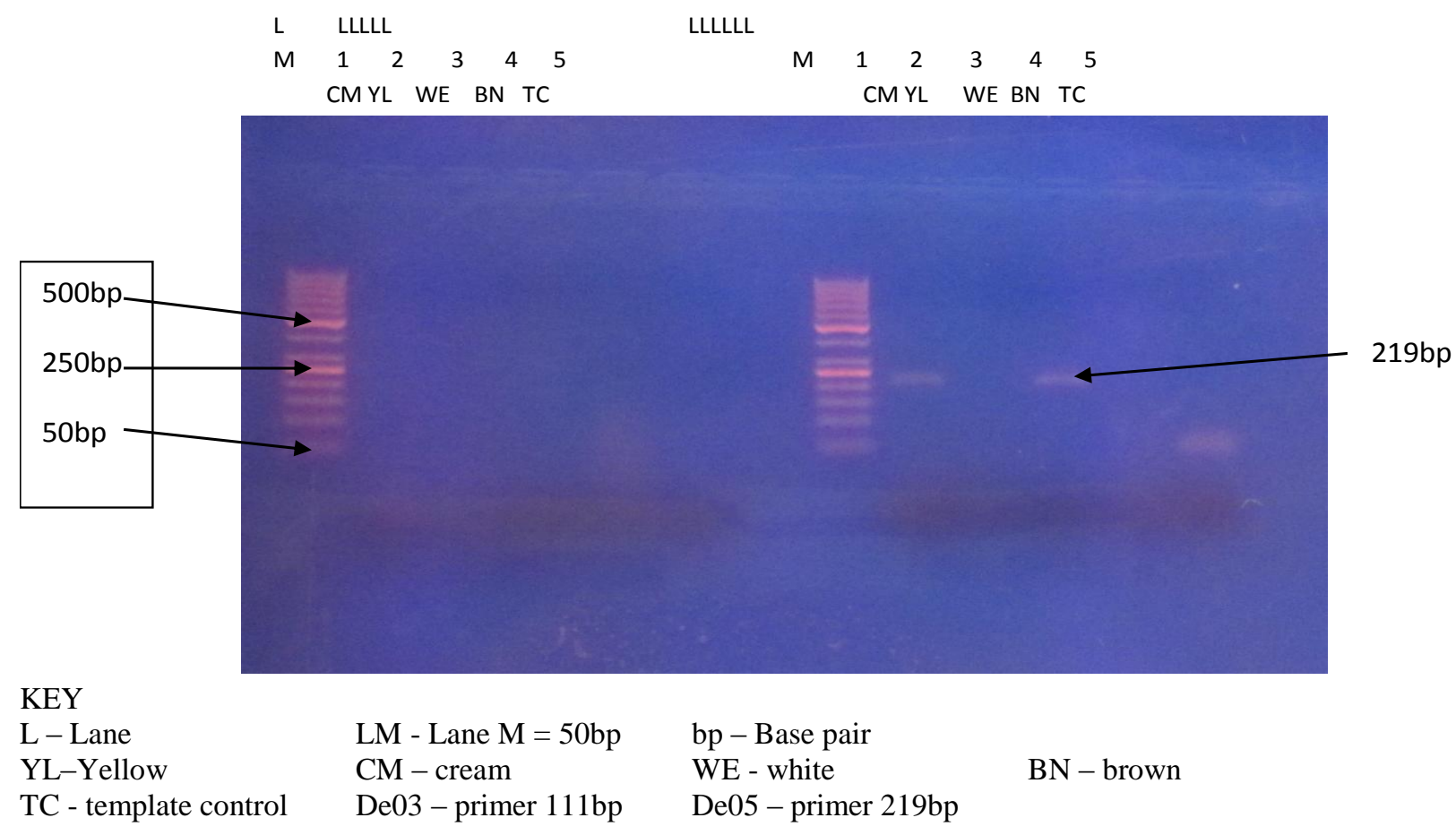

Fig.4 Gel picture showing the amplification of four Acha types using primers

De23, De30 and De37
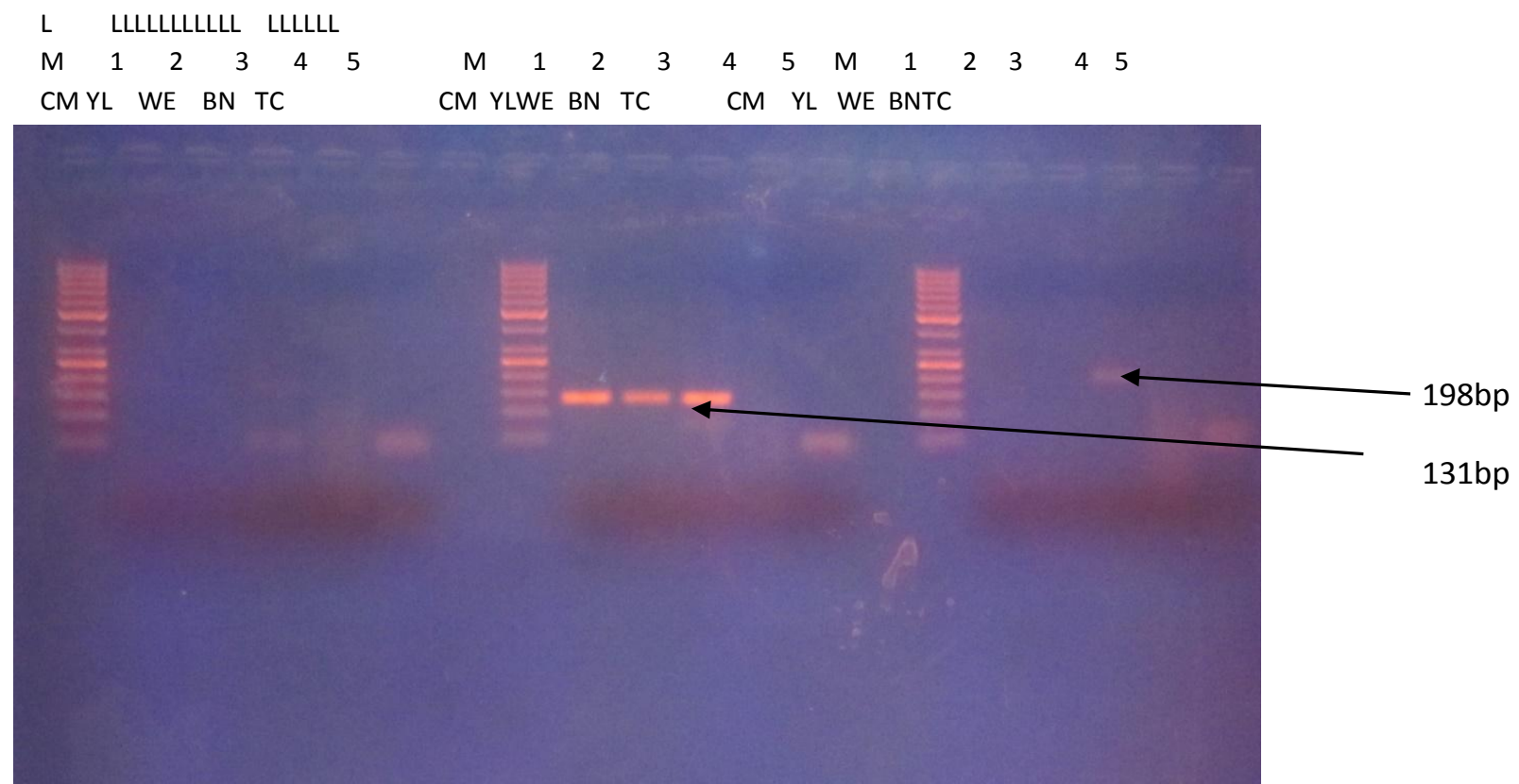

\section{KEY}

L - Lane

YL-Yellow

TC - template control
LM - Lane $\mathrm{M}=50 \mathrm{bp} \quad \mathrm{bp}-$ Base pair

$\mathrm{CM}$ - cream $\quad$ WE - white

De23 - primer 168bp De30 - primer $131 \mathrm{bp}$
$\mathrm{BN}$ - brown

De37 - primer 198bp 
Water absorption of the grains for the two temperatures used followed an exponential pattern. There was an initial rapid rate within the first 1hour, which later reduced and become steady from 6hours up to $24^{\text {th }}$ hours of steeping Figure 2. The significant difference seen in the water absorption rate from 16hours was due to the fact that during the soaking of food materials water is progressively being absorbed, (Addo et al., 2006). While between 6 and $24^{\text {th }}$ hours there was no significant difference in the four Acha types, and that was why the sixth hour was swallowed up in the $24^{\text {th }}$ hours in the graph. It was so because the grain has reached its moisture absorption capacity. This accurate description of the moisture absorbed by cereal during soaking is relative to soaking time and temperature which are essential in order to achieve optimum water content of the described process, (Seyhan-Gurtas et al., 2001).

The summary of the analysis in table 3 showed that the yellow, brown and white colour types are not significantly different at p-value confidence level

\section{PCR Result}

Out of the five (5) set of micro satellite primers used to test the four Acha grain types, two did not amply the grain, while two presented a clear multilocus pattern and one has a unique amplification site, figure 3 and 4. A maximum of three alleles were found per locus. This reveals a clear genetic relationship and difference between the Acha types, meaning not all Acha types are the same they are of different varieties, evethough they have some similarities. This agrees with the report of CIRAD (2004), which says there are over 300 digitaria species which are sometimes grown as fodder only three or four are sometimes grown as cereals. Similarly Istifanus and Agbo (2016), also identified fourteen different varieties of Acha grain which differ from each other in their physioco-chemical attributes.

The study reveals that temperatures help to accelerate the rate of water absorption of food materials, as the water absorption at $50^{\circ} \mathrm{c}$ was more rapid than at $35^{\circ} \mathrm{c}$. All the four types of Acha grain stopped absorbing water between 6th and 24th hours because they have reached their water absorption capacity.

The findings has enable us have the understanding that Acha grain differs from each other which was seen in the water absorption behavior and the genetic variation using PCR.

\section{Recommendations}

There is need for more genetic characterization and the sequencing of the different types of Acha grain, which will reveal a lot of information on the taxonomy, cytogenetics and compatibility of the grain.

In view of the above, a collaborative effort from the government and academia in Nigeria is necessary to tackle the problem.

\section{References}

Addo, A. Bart - plange, A. and Dzisi, K. (2006). Water absorption characteristics of obatanpa and mamaba maize hybids (Zea mays). International Journal of food Engineering, 2 (3), Art 7 DOI: 10.2202/1556 - 3758. 1067.

Barnaud, A. Vignes H. Risterucci A. M., Noyer, J.L. Pham, J. L. Blay, C. Buiron, M., Vigouroux, Y. and Billot C. (2016). Development of Nuclear Microsatellite markers for the Fonio, Digitariaexilis (poaceae), an understudied West African cereal. American Journal of Botany. Primer notes and protocols in 
the plant science e105 - e107, http://www.amjbot.org/@2012

Botanical society of Ameria e105

CIRAD, (2004). An African cereal crop. French Agricultural Research Centre for International Fonio.Cirad.fr/en/the-plant

Istifanus, M.F. and Agbo, E.B. (2016). Survey and identification of Acha varieties in some local governments of Plateau and Bauchi state, Nigeria. The international Journal of science and technoledge, 4(10):52-57.

Kwon-Ndung, E.H. and Dachi, S.N (2007). Acha (Fonio) genotypic diversity and Management in Nigeria. African crop science society conference proceedings 8:787-790.

Seyham - Gurtas, F., A. K., M. M., and Evranuz, E. O. (2001). Water diffusion coefficients of selected legumes grown in Turkey as affected by temperature and variety. Turkish Journal of Agriculture 25: 297 - 304
Shittu, T. A. Awonorin, S. O., and Raji, A. O. (2004). Evaluating some empirical models for predicting water absorption in African Breadfruit (Treculia Africana) seeds. International Journal of foodproperties, 7 (3), 585 - 602

Sopade, P.A., and Obekpa, J. A. (1990). Modelling water absorption in soybean, cowpea and Peanuts at three temperatures using peleg's equation. Journal of food science, 55, 1084 1087

Tagawa, A., Muramatsu, Y., Nagasuna, T. Yano A., Iimoto, M. and Murata S. (2003). Water absorption characteristics of wheat and barley during soaking. Transactions of the ASAE 46 (2): 361 366

Yin, D. Zhang, X., Cui, D., and Liu, H. (2011). A protocol for extraction of high quality RNA and DNA from peanut plant tissues. Journal of molecular biotechnology 49: 187-191

\section{How to cite this article:}

Istifanus M. F., E. B. Agbo and Umar A. F. 2018. Water Absorption and the Genetic Relationship of Four Different Types of Acha (Digitaria exilis) Grains Using PCR. Int.J.Curr.Microbiol.App.Sci. 7(06): 3464-3472. doi: https://doi.org/10.20546/ijcmas.2018.706.406 